\title{
A Survey of Historic Caddo Sites in Nacogdoches County, Texas
}

Tom Middlebrook

Heritage Research Center, Stephen F. Austin State University

Follow this and additional works at: https://scholarworks.sfasu.edu/ita

Part of the American Material Culture Commons, Archaeological Anthropology Commons, Environmental Studies Commons, Other American Studies Commons, Other Arts and Humanities Commons, Other History of Art, Architecture, and Archaeology Commons, and the United States History Commons

Tell us how this article helped you.

This Article is brought to you for free and open access by the Center for Regional Heritage Research at SFA ScholarWorks. It has been accepted for inclusion in Index of Texas Archaeology: Open Access Gray Literature from the Lone Star State by an authorized editor of SFA ScholarWorks. For more information, please contact cdsscholarworks@sfasu.edu. 


\section{A Survey of Historic Caddo Sites in Nacogdoches County, Texas}

Creative Commons License

(c) (i) (8)

This work is licensed under a Creative Commons Attribution-NonCommercial 4.0 International License 


\section{A SURVEY OF HISTORIC CADDO SITES IN NACOGDOCHES COUNTY, TEXAS}

\section{Tom Middlebrook}

This review was originally prepared for presentation to the East Texas Caddo Research Group held in Nacogdoches, Texas on December 2 and 3, 2006. The primary purpose of this article is to summarize the archaeological resources currently known relating to the Historic Caddo period of Nacogdoches County. No attempt is made here to provide analysis of the data or to draw synthetic conclusions. The author's hope is that this survey will be helpful to workers in this area of inquiry by speeding access to available resources and exposing possible research problems.

\section{Introduction}

Nacogdoches County lies at one of the epicenters of Hasinai interaction with Europeans during the Historic Caddo Period (ca. A.D. 1680-1850). Although the DeSoto/Moscoso expedition may have traveled in the area during the 1540 s and LaSalle's party almost certainly walked through portions of the county between Cenis (the French word for the Hasinai) and the Nasoni village in the 1680s, no substantial and full time European presence occurred until Fray de Espinosa founded Mission Concepcion on July 7, 1716 near the principal village of the Hainai on the Angelina River. Days later Fray Margil, also of the Ramon expedition, established Mission Guadalupe in the present-day City of Nacogdoches and Mission San Jose to the Nasoni near Cushing and a few hundred $m$ north of the Nacogdoches County line.

A re-supply expedition by Martin de Alarcon in 1718 did little to aid the missions stressed by disease and drought. After Spain and France re-engaged in European warfare, the Spanish East Texas missions collapsed back to Bexar following a minor skirmish with the French known as the "Chicken War" in 1719. The missions in Nacogdoches County were reopened by the Aguayo Expedition in 1721 and were strengthened by the re-location of Presidio Dolores from near the Neches River (and Mission San Francisco) to Legg Creek about a league east of Mission Concepcion. The three western Queretaran missions and the presidio were again closed and removed back to Bexar by 1730 after a negative inspection review from Pedro de Rivera y Villalon in 1727. The Zacatacan Mission Guadalupe to the Nacogdoche remained in ministry until 1773.

Gil Y Barbo led a group of settlers originally from Presidio Los Adaes, and living for several years on the Trinity River at Bucareli, back into East Texas in 1779 and established the Spanish town of Nacogdoches not far from the old Mission Guadalupe. For the next 40 years there existed a dynamic interaction around Nacogdoches between the Caddo (whose numbers had been greatly reduced by devastating epidemics), new immigrant Native American groups, the Spanish settlers, and the French traders who had been in and out of the area since the mid- $18^{\text {th }}$ century. The flood of Anglo-Americans 
into East Texas following Mexican Independence in 1821 and Texas Independence 15 years later resulted in depredations and forceful removal of native peoples in East Texas. Some Hasinai people married Europeans and stayed in the county in pockets near Chireno and along Morral Creek. Other small groups may have stayed until the 1840 s on small farmsteads.

The net effect of contact with Europeans on Hasinai Caddo society and life ways can only be seen as ultimately catastrophic for groups that lived in the area. But the archaeological data illuminating the processes and changes in the aboriginal culture during the Historic Caddo period are spotty and often poorly analyzed. The purpose of this article is to describe the known archaeological sites related to the Historic Caddo in Nacogdoches County and to sketch some of the data currently available concerning their material culture. This information may be useful in our understanding methods of identifying Historic sites and in helping formulate the most efficient strategies/questions for future research.

\title{
Overview of Historic and Possible Historic Caddo Sites in Nacogdoches County
}

\author{
Previous Reviews
}

The three key early Spanish sites in Nacogdoches County, namely Missions Concepcion and Guadalupe and Presidio Dolores, have not been identified in the modern era. Three prior lists have been made of Historic Caddo sites in the county. These will be described here:

Table 85 in Story et al. (1990):

41NA113, Deshazo (41NA27), Mayhew (41NA21), J.T. King (41NA15)

Table 2.6.1 in Kenmotsu and Perttula (1993):

41NA15, 41NA21, 41NA22, 41NA23, 41NA27, 41NA60, 41NA67, 4INAII3, ET-882, ET-881

Comment: "vessels, glass trade beads reported in 1930s" mentioned under 41 NA23 almost certainly refers to 41NA27.

Table 1 and 2 in Marceaux (2006:14-15):

Historic and Potentially Historic Sites in the Study Area: 41NA139 (Park Street Dump Site), 41NA171, 41NA202 (Stevens Site), 41NA207, 41 NA208 (E. Wayne Boozer), 41NA22, 41 NA223 (Mission Church Guadalupe del Pilar 1804).

Allen phase sites to be included: 41NA113,41NA15 (J. T. King), 41NA183 (Loco Fork), 41 NA 197 (Sam Stripling), 41 NA206 (Steve 
Spradley), 4INA23 (Deshazo), 41NA27 (Deshazo), 41NA60 (Henry Mast), 41 NA67.

Comment: Park Street Dump Site is a $19^{\text {th }}$ century dump and does not have historic Caddo material; 41 N17l's "historic trash" does not relate to Historic Caddo but a separate component; 41 NA197 is not Allen phase; 41NA23 is the Loco Bottoms Site.

\section{Summary of Current Review}

For this article, 29 sites have been identified (often overlapping with the previous lists). Table 1 enumerates the sites, the major drainage in which the sites are located, the presence of historic European artifacts, and some description of the main artifact types.

Because surface treatment of utility ceramic wares may prove to be a helpful tool in distinguishing various Historic Caddo groups, three statistics are presented as part of Table 1 providing some measurement of the frequency of brushing as a decorative or functional surface treatment: (1) \% $\mathbf{B r}$ is simply the percentage of all sherds with brushing as the only surface treatment; (2) $\mathbf{B r} / \mathbf{P l}$ is the ratio of brushed sherds to plain/undecorated sherds; and (3) $\% \mathbf{B r} / \mathbf{B r}+\mathbf{P I}$ is the percentage of the sherds with brushing out of all sherds that do not have the more elaborate decorative styles such as incised, engraved, or punctated. This percentage is comparable to, but usually higher than, the "\% Brushed" figure.

Table 1. Summary of Historic and Possible Historic Caddo Sites in Nacogdoches County.

\begin{tabular}{|c|c|c|c|c|c|c|c|c|c|c|}
\hline Site \# & Site Name & Drainage & $\begin{array}{l}\text { Hist } \\
\text { oric }\end{array}$ & $\begin{array}{l}\text { Total } \\
\text { Sherd }\end{array}$ & $\% B r$ & BriPI & $\begin{array}{l}\% B r / B r \\
+P I\end{array}$ & Ceramic Types & Lithics & Historic \\
\hline 41NA15 & King & Angelina & yes & 198 & 54 & 4.29 & 81.1 & $\begin{array}{l}\text { Patton }=22 \text {, Poynor }=1 \text {, neck } \\
\text { banded, pinched }\end{array}$ & none & beads in burial \\
\hline 41NA18 & & Loco & & 107 & 57.9 & 1.55 & 60.8 & & $\begin{array}{l}\text { Clifton, } \\
\text { Perdiz=2 }\end{array}$ & none \\
\hline 41NA21 & Mayhew & Loco & yes & 20,428 & 46.2 & 1.21 & 54.7 & $\begin{array}{l}\text { Patton }=1696, \text { Natchitoches }=69 \text {, } \\
\text { Emory }=11 \text {, neck banded, } \\
\text { brushed punc, pinch appliqued }\end{array}$ & $\begin{array}{l}\text { Perdiz, } \\
\text { Fresno, Maud }\end{array}$ & $\begin{array}{l}\text { glass beads }=34 \text {, glass, } \\
\text { brass kettle, nails }=6 \text {, } \\
\text { gunflints }=6 \text {, gun barrel, } \\
\text { trigger plate, butt plate, } \\
\text { flintlock cock, lead ball }\end{array}$ \\
\hline 41 NA22 & Iron Rock & Loco & yes & 4,017 & 48.7 & 1.34 & 57.3 & $\begin{array}{l}\text { Patton=29, Poynor=77, Killough } \\
\text { Pinched=8, neck banded=11, } \\
\text { Brlnc=58, } B r P n=60 \text {, } \\
\text { BrApplig=97 }\end{array}$ & & glass bead $=1$ \\
\hline 41NA23 & $\begin{array}{l}\text { Loco } \\
\text { Boltoms }\end{array}$ & Loco & & 4,088 & 43 & 1.15 & 53.5 & $\begin{array}{l}\text { Patton=72, Poynor }=51, \text { neck } \\
\text { banded }=31, \text { BrAppliq }=64 \text {, } \\
\text { pipe }=16\end{array}$ & $\begin{array}{l}\text { Friley }=3, \\
\text { Perdiz }=3\end{array}$ & none \\
\hline
\end{tabular}




\begin{tabular}{|c|c|c|c|c|c|c|c|c|c|c|}
\hline & & & & & & & & & $\begin{array}{l}\text { Scallorn=7 } \\
\text { Colbert=12, } \\
\text { Other=33 }\end{array}$ & \\
\hline 41NA29 & Perkins & Loco & & 52 & & & & (missing@ @ TARL) & arrow point & ground hist sherd=1 \\
\hline 41 NA33 & $\begin{array}{l}\text { Legg Creek } \\
\# 1\end{array}$ & Legg & & 35 & 57.1 & 5 & 83.3 & Patton $=2$ & none & none \\
\hline 41NA44 & Chaya & Legg & & 2440 & 34.1 & 1.07 & 51.8 & $\begin{array}{l}\text { Patton }=34, \text { Poynor }=7 \text {, Avery=2, } \\
\text { Maydelle }=9 \text {, } \\
\text { brushed/incised }=41 \text {, } \\
\text { punctated }=142 \text {, } \\
\text { punctincised }=23 \text {, } \\
\text { brush/punctated }=100 \text {, } \\
\text { appliqued }=49, \text { pipe }=15\end{array}$ & $\begin{array}{l}\text { projectile } \\
\text { points=14 } \\
\text { (many are dart } \\
\text { points). } \\
\text { Perdiz=1, } \\
\text { Bassett=1 }\end{array}$ & none \\
\hline 41NA47 & $\begin{array}{l}\text { Legg Creek } \\
\# 5\end{array}$ & Legg & & 50 & 40 & 1.43 & 58.8 & $\begin{array}{l}\text { Patton }=3(?) \text {, } \\
\text { brushed/punctated=5, } \\
\text { incised }=7\end{array}$ & none & none \\
\hline 41NA53 & $\begin{array}{l}\text { Legg Creek } \\
\# 10\end{array}$ & Angelina & & 60 & 70 & 2.8 & 73.7 & incised $=2$ & none & none \\
\hline 41NA54 & $\begin{array}{l}\text { Cocil } \\
\text { Sparks }\end{array}$ & Angelina & & 516 & 70.2 & 3.8 & 79 & $\begin{array}{l}\text { incised=12, punctated=9, } \\
\text { brushed/punct=6, appliqued=3, } \\
\text { pinched=2, Patton=1, pipe =3 }\end{array}$ & Perdiz=1 & none \\
\hline 41NA55 & $\begin{array}{l}\text { Legg Creek } \\
\# 12\end{array}$ & Angelina & & 17 & 29.4 & 0.83 & 45.4 & incised $=3$, other $=3$ & none & none \\
\hline 41 NA60 & Henry M & Loco & yes & 418 & 63.4 & 5.2 & 83.9 & $\begin{array}{l}\text { Patton=16, Other } \\
\text { Engraved=31, Incised=14, } \\
\text { Punctated }=17 \text {, Neck banded=1 }\end{array}$ & $\begin{array}{l}\text { arrow } \\
\text { points }=10\end{array}$ & glass bead $=1$ \\
\hline 41NA65 & $\begin{array}{l}\text { Loco } \\
\text { Bayou } \\
\# 109\end{array}$ & Loco & & 27 & 70.4 & 2.7 & 73 & & none & none \\
\hline 41NA67 & $\begin{array}{l}\text { Sam } \\
\text { Rayburn } \\
\# 101\end{array}$ & Attoyac & yes & 458 & 7.2 & 0.12 & 10.7 & $\begin{array}{l}\text { incised=72, punct/incised }=27 \text {, } \\
\text { brushed/punct }=1 \text {, neck } \\
\text { banded }=1 \text {, engreved=6, } \\
\text { punctated }=37 \text {, Patton }=2 \text { ? }\end{array}$ & $\begin{array}{l}\text { Perdiz=7, } \\
\text { Friley }=2 \text {, } \\
\text { Maud }(?)=1 \\
\text { Bassett }=1\end{array}$ & $\begin{array}{l}\text { Brass tinkier=1, blue glass } \\
\text { bead=1, historic blue floral } \\
\text { painted sherd=1 }\end{array}$ \\
\hline 41NA111 & Dick Shipp & LOCO & & 196 & 69.4 & 5.44 & 84.5 & & & none \\
\hline 41NA113 & & Lanana & yes & 22 & & & & $\begin{array}{l}\text { "mainly sandy paste - } \\
\text { punctated \& brushed" }\end{array}$ & none & $\begin{array}{l}\text { "burial containing two } \\
\text { small ceramic vessels, } \\
\text { glass trade beads and } \\
\text { shell beads. One vessel is } \\
\text { Patton Engraved." }\end{array}$ \\
\hline 41NA187 & Loco Fork & Loco & yes & $>500$ & & & & & & broken white glass bead \\
\hline 41NA202 & Stevens & Loco & yes & & & & & per RL Tumer, Jr, & & glass beads \\
\hline 41NA206 & $\begin{array}{l}\text { Steve } \\
\text { Spradiey }\end{array}$ & Lanana & yes & & & & & per SFASU & per SFASU & per SFASU \\
\hline 41NA223 & $\begin{array}{l}1804 \\
\text { Guadalupe } \\
\text { del Pilar }\end{array}$ & Lanana & yes & & & & & per SFASU & & per SFASU \\
\hline $\begin{array}{l}\text { Un- } \\
\text { recorded }\end{array}$ & Joe Little & Altbyac & yes & $>200$ & & & & $\begin{array}{l}13 \text { vessels: } 6 \text { botties, } 3 \text { bouts, } 3 \\
\text { jars, one earthenware "pitcher; } \\
\text { Natchitoches Engraved=2 }\end{array}$ & & \\
\hline $\begin{array}{l}\text { Un- } \\
\text { recorded }\end{array}$ & A.L. Self & Angelina & yes & & & & & & & $\begin{array}{l}\text { "Indian Stone Pipes, } \\
\text { Indinan Bowls, Indina } \\
\text { Beads, a Ring. Human } \\
\text { Bones" }\end{array}$ \\
\hline $\begin{array}{l}\text { Unt- } \\
\text { recorded }\end{array}$ & $\begin{array}{l}\text { W.T. } \\
\text { Williamson }\end{array}$ & Angelina & yes & & & & & & & burials with beads \\
\hline $\begin{array}{l}\text { Un- } \\
\text { recorded }\end{array}$ & $\begin{array}{l}\text { Appleby } \\
\text { Bead }\end{array}$ & Lanana & yes & & & & & & & RLT report of beads \\
\hline $\begin{array}{l}\text { Un } \\
\text { recorded }\end{array}$ & $\begin{array}{l}\text { Nac East } \\
\text { Bead }\end{array}$ & Lanana & yes & & & & & & & RLT report of beads \\
\hline
\end{tabular}

Figure 1 displays the approximate locations of the 29 sites. Sixteen sites are considered to be confirmed Historic Caddo sites on the basis of European trade goods; 13 are possible Historic Caddo sites but currently lack evidence of European material. The sites will be described in groups based upon the drainages they are found in as these may represent individual constituent groups (but this assumption needs to be tested). There 
are seven sites in the Angelina River drainage, three in the Legg Creek drainage, 12 in the Loco Bayou, five in the Lanana, and two in the Attoyac Bayou drainage. The reported sites have received varying levels of investigation: seven have seen controlled excavation; six sites have received limited testing with shovel tests, few small excavation units, or backhoe trenching; 12 have only been surface collected, and four have received unknown levels of field study.

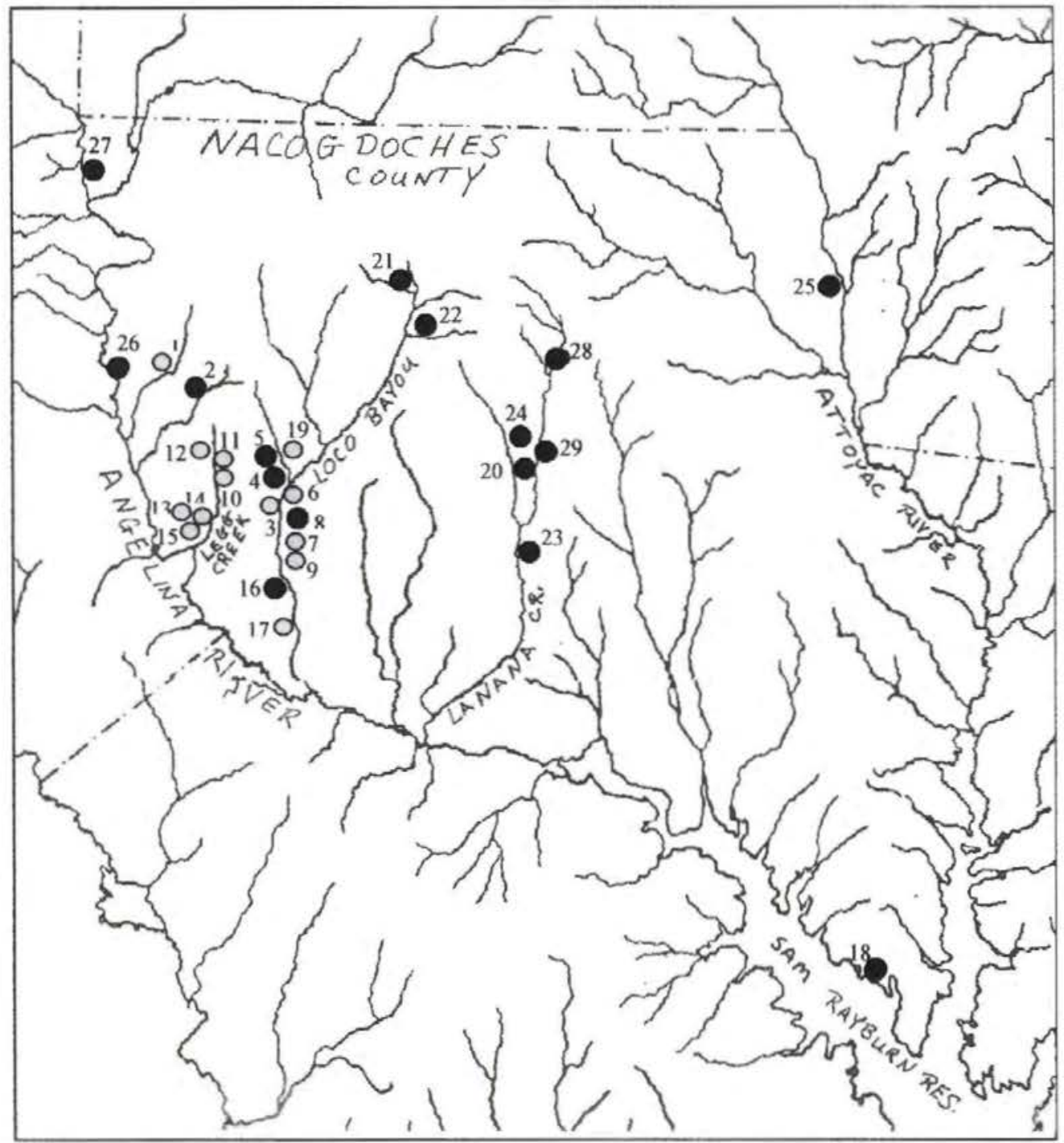

Figure 1. Known and possible Historic Caddo sites in Nacogdoches County, Texas. Black circles $=$ location of Historic Caddo sites; Gray circles $=$ location of possible Historic sites

1-NA6 Dorsey

2-NA King

3-NA18

4-NA21 Mayhew

5-NA22 Iron Rock

6-NA23 Loco Bottom

7-NA26

8-NA27 Deshazo
9-NA29 Perkins

10-NA33

11-NA44 Chaya

12-N $\Lambda 47$

13-N53

14-NA Cecil Sparks

15-NA55

16-NA60 Henry M
17-NA65

18-NA67

19-NA111 Dick Shipp

20-NAI13

21-NA 187 Loco Fork

22-NA202 Stevens

23-NA206 Steve Spradley

24-NA223 Guadalupe Pilar
25-Joe Little

26-AL Self

27-WT Williamson

28-Appleby Bead

29-Nac. East Bead 


\section{Angelina River Sites}

Despite the Angelina River being the area of the establishment in 1716 of Mission Concepcion in the principal Hainai village (and the residence of the Grand Xinesi of the Hasinai), only modest archaeological evidence for Historic Caddo has been reported in this drainage. The two sites near the river with European beads mentioned by A. T. Jackson in the 1930s have never been found on the ground. Two other sites with recent locational confirmation are up side tributaries and some distance from the main river channel. Three other sites near the confluence of Legg Creek (recorded by Tom and Janice Mayhew) hold some promise for future investigation but as yet cannot be identified as Historic Caddo with any certainty.

\section{NA6 Dorsey Site \\ Drainage: Gibbons Creek}

Prior Investigations: Recorded by Gus E. Arnold as "ET-689",2/10/40. Large surface collection made. Re-visited by author 11/12/06 and 11/19/06; small surface collection. Ceramics: Gus Arnold Collection: Plain $=167$, Brushed=565, Incised $=33$, Engraved $=42$ (including Patton=10. Poynor=22), Punctated/Incised=1. Punctated=9, Pipe fragments=2, Other $=49$. TOTAL $=868$. Additional notes: Brushed/Instrument Punctated $=20$,

Brushed/Fingernail Impressed=10, Brushed/Appliqued=6, Node $=1$.

Brushed $\%=65.1 \%$

Middlebrook Collection: Brushed=7, Trailed=1, Undetermined Decoration=1, Blue Edge ware $=1$.

Lithics: petrified wood projectile point $=1$

Historic Artifacts: none

Conclusion: Possible Historic Caddo site.

Research Potential: Gus Arnold's extensive collection available at the Texas Archeological Research Laboratory (TARL). Current landowner has given permission recently for limited exploration of the site.

\section{NA15 J. T. King Site}

Drainage: King Creek

Prior Investigations: Recorded by A. T. Jackson, 4/28/3I. Moderate-sized surface collection made; he reported that three whole vessels, glass beads, and skeleton were found previously in cultivation. Re-visited by author 11/19/06; two shovel tests were dug.

Ceramics: A. T. Jackson Collection: Plain=25, Brushed=107, Incised $=17$, Punctated $/$ Incised $=1$, Punctated $=3$, Engraved $=29$, Other $=15$, Pipe $=1$. Notes: Patton=22, Poynor $=1$, Neck banded=4, Pinched $=1$, Brushed $/$ Appliqued $=2$, Crosshatched $=2$, Unusual Brushed/Incised $/$ Engraved $=4$. TOTAL $=198$.

Brushed \%: $54 \%$

Middlebrook Collection: Plain=9. Brushed=14, Engraved=4 (including Patton=2), sherdlets $=3$.

Lithics: none 
Historic Artifacts: One glass bead found on surface by Jackson; glass beads from reported burial.

Conclusion: Historic Caddo site, Allen phase.

Research Potential: A. T. Jackson's ceramic collection is available in TARL.

Whereabouts of burial material is unknown. Current landowners have given permission for field work at the site. Site is currently endangered by gas well drilling that is ongoing at the time of this writing.

\author{
41NA53 Legg Creek \#10 \\ Drainage: Legg Creek \\ Prior Investigations: Recorded by Mayhew, 1/20/73. \\ Ceramics: Plain $=15$, Brushed $=42$, Incised $=2$. TOTAL $=60$ \\ Brushed $\%=70 \%$ \\ Lithics: none \\ Historic Artifacts: none \\ Conclusion: Possible historic Caddo. \\ Research Potential: Small collection is available at TARL. Current landowner has \\ given permission for limited fieldwork.
}

\title{
41NA54 Cecil Sparks Site
}

Drainage: Legg Creek

Prior Investigations: Recorded and surface collection obtained by Mayhew, 1/20/73. Controlled surface collection made by Stephen F. Austin State University (SFASU) students; Mayhew wrote summary paper 11/8/73. Middlebrook and Texas Archeological Stewardship Network (TASN) Action Team investigated site with five shovel tests, four $1 \times 1 \mathrm{~m}$ units to $20 \mathrm{~cm}$ bs on three dates between $4 / 15 / 06$ and 5/29/06. Ceramics: Combined Mayhew/TARL ( $\mathrm{n}=79)$, SFASU $(\mathrm{n}=181)$, and Middlebrook $(\mathrm{n}=256)$ collections: Plain $=96$, Brushed $=362$, Incised $=12$, Punctated $=9$, Brushed $/$ Punctated=6, Appliqued=3, Pinched=2, Pipe=3, Patton=1. TOTAL=516. Brushed $\%=70.2 \%$

Lithics: Perdiz=1

Historic Artifacts: none Conclusion: Possible Historic Caddo.

Research Potential: Collections available at TARL, SFASU, and the author. Current landowner has given permission for limited fieldwork.

41NA55 Legg Creek \#12

Drainage: Legg Creek

Prior Investigations: Recorded by Mayhew, 12/20/73.

Ceramics: $\quad$ Plain $=6$, Brushed $=5$, Incised $=3$, Other $=3$. TOTAL $=17$.

Brushed $\%=29.4 \%$.

Lithics: no arrow points.

Historic Artifacts: none

Conclusion: Possible Historic Caddo.

Research Potential: Small collection available at TARL. Current landowner has given permission for limited fieldwork. 


\author{
41NA-Unrecorded Site A. L. Self Site \\ Drainage: Angelina \\ Prior Investigations: Report in 1930s of artifacts found by A. L. Self "which I dug up \\ out of the old Indina (sic) camp, here on the Angelina River about 5 miles W of \\ Douglass." \\ Ceramics "Indinan (sic) bowls" \\ Lithics: "Indian stone pipes" \\ Historic Artifacts: "Indina (sic) beads, a ring" \\ Conclusion: Historic Caddo site.
}

Research Potential: See TARL files. No collection available. Location of site currently unknown. Potential may be high if the location of the site can be determined.

\title{
41NA-Unrecorded Site W. T. Williamson Site
}

Drainage: Indian Creek, East Angelina River

Prior Investigations: Report of C. W. Hughes of Waco to A. T. Jackson apparently in the early 1930 s that an Indian cemetery was located on the old King place in Sacul where "pots were plowed up years ago."

Ceramics: "pots"

Lithics: unknown

Historic Artifacts: "trade beads" found at "Bead Pond (pond now filled) a few hundred yards west of where pots were found."

Conclusion: Historic Caddo site.

Research Potential: See TARL files. No collection available. Location of site currently unknown. Potential may be high if the location of the site can be determined.

\section{Search for Mission Concepcion}

During two field seasons between March 2005 and June 2006 the author (with much help from local avocationals and several members of the East Texas Caddo Research Group) attempted to locate Mission Concepcion. The attempt was ultimately unsuccessful, but 19 archeological sites (and five additional single-artifact localities) were identified.

Of the 19 sites, seven had artifacts from early 1900 s house refuse, two had $1800 \mathrm{~s}$ historic components, four yielded minimal Caddo artifacts, two were clearly Archaic, and eight were non-specific lithic scatters. The most important site found on the large tract of International Paper land was "MC-8," which is an early to mid-1800s structure and possibly the location of Samuel Davenport's rancho. Two sites, "MC-12" and "MC-21" may be a part of a Caddo community in the vicinity of the yet-to-be-discovered Mission. Findings from these two sites are too limited to be included in the current review.

\section{Legg Creek Sites}

The three Legg Creek sites were recorded by the Mayhews and investigated by Dr. James Corbin. While no historic European artifacts were recovered in this area, these 
sites may have been on the major trail from the Angelina River to Nacogdoches and may have been near the Presidio Dolores.

\author{
41NA33 Legg Creek Site \#1 \\ Drainage: Legg \\ Prior Investigations: Recorded by T. Mayhew, 8/24/72. \\ Ceramics: Plain $=4$, Brushed $=20$, Incised $=8$, Engraved $=3($ Patton $=2)$. TOTAL $=35$. \\ Brushed $\%=57.1 \%$ \\ Lithics: none \\ Historic Artifacts: none \\ Conclusion: Possible historic Caddo. \\ Research Potential: Small surface collection is available at TARL. Current landowner, \\ Dr. Loyd Michel, has give permission for limited fieldwork.
}

\title{
41NA44 Chayah Site
}

Drainage: Loco

Prior Investigations: Recorded by Mayhew, 12/13/72. SFASU Field School June-July, 1975 under direction of Jim Corbin. $91 \mathrm{~m}^{2}$ excavated.

Ceramics: Plain=775, Brushed $=832$, Brushed $/$ Punctated $=100$, Brushed $/$ Incised $=4 \mathrm{I}$,

Brushed/Appliqued=25, Appliqued=24, Punctated/Incised=23, Punctated $=142$,

Pinched $=17$, Maydelle Incised=9, Patton=34, Poynor $=7$, Avery=2, Pipe $=15$.

TOTAL $=2440$ sherds (3543 objects of clay).

Brushed $\%=34.1 \%$

Lithics: 14 projectile points, Perdiz=1, Bassett $=1$.

Historic Artifacts: none

Conclusion: Possible historic Caddo.

Research Potential: Large collection is available at SFASU. Current landowner has given permission for limited fieldwork.

\section{NA47 Legg Creek \#5}

Drainage: Legg

Prior Investigations: Recorded by Mayhew, 12/16/72.

Ceramics: Plain $=14$, Brushed $=20$, Brushed $/$ Punctated $=5$, Incised $=7$, Engraved $=4$

(Patton=3). (Dee Ann Story TARL re-inventory of 5/23/83 does not list any engraved.)

TOTAL $=50$

Brushed $\%=40 \%$

Lithics: no arrow points

Historic Artifacts: none

Conclusion: Possible historic Caddo.

Research Potential: Small collection available at TARL. Additional fieldwork at the site may be useful; landowner is currently unknown.

\section{Bayou Loco Sites}

The Bayou Loco basin has the highest number of Historic and possible Historic Caddo sites in large measure due to the tireless efforts of avocational archaeologists Tom 
and Janice Mayhew in the 1970s and the Lake Nacogdoches project. But the high number of sites may also reflect some historical realities.

Elton Prewitt (1975) presented a paper outlining the evidence of a Historic Caddo village on the Loco; his evidence includes the following:

1. Bustillo in 1746 suggested placing a mission among the Nabedache on the San Pedro and another in the Hainai village call El Loco located between the Angelina River and Nacogdoches (Bolton 1915: 167).

2. The Fragoso Diary of the Vial Expedition noted on October 24, 1788 "we set out to the southwest from this pueblo (Nacogdoches) ... in the afternoon stopped at El Loco, a well known place; we made four leagues".

3. In 1779, Gil Y Barbo mentioned seeing a village of the Texas three leagues west of Nacogdoches.

4. In 1828, Lt. Sanchez crossed El Loco west of Nacogdoches and reported seeing a village of the Texas, Hainai and the Nacogdoche (see Berlandier 1969: 149).

\section{NA18}

Drainage: Loco

Prior Investigations: Recorded by D. Brown, E. Prewitt, 7/11/72. Previously visited by Tom Mayhew.

Ceramics: Plain $=40$, Brushed $=62$, Incised $=3, P / 1=0$, Punctated $=2$, Engraved $=0-1$.

TOTAL $=107$

Brushed \%: $57.9 \%$

Lithics: Cliffton=1, Perdiz=2.

Historic Artifacts: none

Conclusion: Possible historic Caddo site.

Research Potential: Collection at TARL. Site unavailable; under waters of Lake Nacogdoches.

\section{NA21 Mayhew Site}

Drainage: Loco

Prior Investigations: Recorded by V. Holliday, 7/11/72. Excavated under supervision of E. Prewitt, April 1975. In 15 field days, $552 \times 2$ m units opened $\left(220 \mathrm{~m}^{2}\right)$, mostly to 10 $15 \mathrm{~cm}$ bs (see Kenmotsu 1992).

Ceramics: Plain $=7835$, Brushed $=9447$, Incised $=529+$, Patton $=1595$ body sherds +101 rims, Emory=11, Natchitoches $=69$, pipe $=7$. Others: Neck banded, Brushed/Punctated, Punctated, Parallel Vertical Incised, Pinched/Appliqued, Diagonal Incised, Horizontal Incised, etc. TOTAL $=20,428$.

Brushed \%: $46.2 \%$ (but by weight, 3:1 Brushed:Plain). Lithics: Perdiz=-1, Fresno=8, Maud=1. Gunflints=6 $($ Native $=4$, French $=2)$. Historic Artifacts: Glass fragments $=5$, Brass Kettle $=4$, Nail=6, chisel=1, Other Metal $=17$, Gunflints $=4$ (native) +2 (French), Gun Barrel=1, Trigger Guards $=2$, Side Plate Gun Fragment=I I1, Butt Plate=4, Side Plate Screw=2, guncock=1, Iron Ram Rod=2, Lead Ball $=6$. Glass Beads $=34$, chunk of partially melted beads $=1$. 
Conclusion: Historic Caddo site, Allen phase

Research Potential: Extensive collection is available at TARL. Decorated sherds need to be re-analyzed. Site is unavailable; under waters of Lake Nacogdoches.

\section{NA22 Iron Rock Site (also Red Gate Site)}

Drainage: Loco

Prior Investigations: Surface collection, T. Mayhew, 3/18/72. Recorded by D. Brown, 7/11/72. Surface collection, backhoe trenches and test pits by E. Prewitt 4/14-29/75.

Ceramics: (Approximate numbers) Plain $=1448$, Brushed $=1947$, Other Decorated $=408$, Rims $=181$, Base $=33$. Notes: Patton $=29$, Poynor $=77$, Pinched $=8$, Brushed $/$ Incised $=58$, Pease Brushed/Incised=2, LaRue Neck Banded=11, Incised $=165$, Brushed $/$ Appliqued $=97$, Brushed $/$ Punctated $=60$, Brushed $/$ Punctated $/$ Appliqued $=48$, Pipes $=23$. TOTAL $=4017$.

Brushed \%: $48.7 \%$

Lithics: Fresno=1, Friley $=1$, Bassett $=4$, Perdiz $=8$.

Historic Artifacts: Glass bead (white) $=1$

Conclusion: Historic Caddo site. Allen phase.

Research Potential: Moderately large collection of sherds are available at TARL. Site is unavailable; under waters of Lake Nacogdoches.

\section{NA23 Loco Bottoms Site}

Drainage: Loco

Prior Investigations: Recorded by T. Mayhew, 7/12/72. Prewitt surface collection. Excavation 3/18/72-6/24/72 on 11 dates by the Nacogdoches Archeological Society. Total of 12 contiguous $5 \times 5 \mathrm{ft}$ units plus 3 "test pits" excavated comprising $375 \mathrm{ft}^{2}$ or $34.84 \mathrm{~m}^{2}$. One $3 \mathrm{~m}$ pit feature identified.

Ceramics: $\quad P l a i n=1529$, Brushed $=1758$, Decorated $=616$, Rim $=141$, Basal $=28$, Notes:

Patton $=72$, Poynor $=51$, Neck banded/Ridged $=31$, Brushed $/$ Incised $=15$,

Punctated/Incised $=8$, Punctated $=35$, Brushed $/$ Appliqued $=24$,

Brushed $/$ Punctated $/$ Appliqued $=64$, Crosshatched $=9$, Pipe $=16$. TOTAL $=4088$.

Brushed $\%=43 \%$

Lithics: Friley $=3$, Perdiz $=3$

Historic Artifacts: none

Conclusion: Possible Historic Caddo. Multi-component site but predominantly protohistoric/historic.

Research Potential: Large sherd collection available at TARL. Site is unavailable; under waters of Lake Nacogdoches.

\section{NA26}

Drainage: Loco

Prior Investigations: Recorded by E. Prewitt, 7/13/72. Surface collection 7/10/75 D. A.

Story, E. Prewittt, and T. Mayhew.

Ceramics: $\quad$ Plain $=8$, Brushed=12, Patton Engraved=1, Fine line Engraved $=1$.

TOTAL $=22$.

Brushed $\%=54.5 \%$

Lithics: no arrow points 
Historic Artifacts: none

Conclusion: Possible Historic Caddo.

Research Potential: Very small collection at TARL. Site is unavailable; under waters of Lake Nacogdoches.

41NA27 Deshazo Site

Drainage: Loco

Prior Investigations: Excavation of nine burials by Robert L. Turner, Sr. and R. L. Turner, Jr. during 1937-1939. Surface collection and recording by Gus Arnold, 1940. Visit and recording by E. Prewitt, summer 1972. Excavation by Texas Archeological Salvage Project under direction of E. Prewitt, April-May, 1975. University of Texas Field Schools under direction of Dee Ann Story during summer 1975 and 1976. Excavation of 4 square $m$ in October 1975 by Jim Corbin and students. Excavations totaled $744 \mathrm{~m}^{2}$ and $186 \mathrm{~m}^{3}$ plus backhoe trenching.

Ceramics: Plain $=6974$, Brushed $=20254$, Decorated $=3397$. Notes: Patton $=776+$, Poynor $=27$, Neck banded=7, Appliqued $=108$, Pinched $=3$. Pipe sherds $=165$. Temper: Grog $=83 \%$, Bone+Grog $=17 \%$. TOTAL $=30,625$.

Brushed $\%=66.1 \%$.

Vessels: (13 vessels from nine Turner burials in cemetery; three vessels from three juvenile burials in residential areas) Plain $=4$, Brushed $=3$, Punctated $=1$, Incised=1, Patton $=4$, Other Engraved $=3$.

Lithics: Arrow points $=226$; Cliffton-like $=49$, Perdiz/Bassett $=118$, Cliffton $/ F r i l e y=4$, Cuney $=3$, Scallorn $=7$, Colbert $=12$, Other $=33$.

Historic Artifacts: Glass beads=4646; 4 beads from 1970s excavations, 630 from Turner burials 2 and 4, and 4012 "thought to have come from the cemetery". Metal: knife blades $=3$ (burials), copper alloy hand bell $=1$ (burial), lead bullet=4, gun worm $=1$. Conclusion: Historic Caddo site.

Research Potential: Extensive collection available at TARL. Burial goods with Robert Turner, Jr. Future research will need to refine descriptions of brushed wares and distinguish between incised and engraved sherds. Site is unavailable; under the waters of Lake Nacogdoches.

\section{NA29 Perkins Site}

Drainage: Loco

Prior Investigations: Recorded by D. Brown, 7/13/72.

Ceramics: 52 aboriginal sherds. (Missing from TARL.)

Lithics: arrow point $=1$

Historic Artifacts: "ground historic sherd" $=1$

Conclusion: Possible Historic Caddo.

Research Potential: No collection is available at TARL. Author has seen a small collection in possession of Perkins family; general impression was that the artifacts were consistent with a Historic Caddo occupation. Site located in garden may be available for additional investigation.

\section{NA60 Henry M Site}


Drainage: Loco

Prior Investigations: Recorded by Mayhew, 3/4/73. Excavation conducted/sponsored by author on 56 dates between 5/11/85 and 10/5/91. Approximately $55 \mathrm{~m}^{2}$ and $22 \mathrm{~m}^{3}$ excavated; artifact lots $=258$.

Ceramics: Summary of 45 lots representing $10 \mathrm{~m}^{2}$ and $2.9 \mathrm{~m}^{3}$ : Plain $=51$, Brushed $=265$, Patton $=16$, Other Engraved $=31$, Incised $=14$, Punctated $=17$, Base sherds $=3$, Neck banded $=1$, Other Fired Clay Objects $=18$. TOTAL $=418$. (Over 300 sherdlets not analyzed.)

Brushed $=63.4 \%$

Lithics: arrow points $=10$.

Historic Artifacts: glass bead $=1$

Conclusion: Historic Caddo site.

Research Potential: Collections are available at TARL and with author. Author owns site, and it is available for additional fieldwork.

\section{NA65 Loco Bayou \#109}

Drainage: Loco

Prior Investigations: Recorded by Mayhew, 9/12/73.

Ceramics: Plain $=7$, Brushed $=19$. TOTAL $=27$.

Brushed $\%=70.4 \%$

Lithics: no arrow points

Historic Artifacts: none

Conclusion: Possible historic Caddo.

Research Potential: Mayhew collection not at TARL. Availability of site for further fieldwork is unknown.

\section{NA111 Dick Shipp Site}

Drainage: Loco

Prior Investigations: Recorded by Jim Corbin in June, 1992.

Ceramics: Plain $=25$, Brushed $=136$, Brushed $/$ Punctated $=3$, Brushed $/$ Appliqued $=7$,

Brushed $/$ Incised $=2$, Pinched $=5$, Appliqued/Engraved $=1$, Punctated/Engraved $=1$,

Noded $=1$, Engraved $=8$, Basal $=7$. TOTAL $=196$. (Also 150 sherdlets)

Brushed $\%=67.9 \%$

Lithics: no arrow points

Historic Artifacts: none

Conclusion: Possible Historic Caddo.

Research Potential: Collection at SFASU; landowners have collection. Landowners have given permission for limited fieldwork.

\section{NA183 Loco Fork Site}

Drainage: Loco

Prior Investigations: Recorded by author, 5/30/91. Surface Collection, $21 \times 1 \mathrm{~m}$ units and eight shovel test excavated between 1986-1996.

Ceramics: $>500$ sherds; not yet analyzed.

Lithics: pending analysis.

Historic Artifacts: half of white-striped glass bead. 
Conclusion: Historic Caddo site.

Research Potential: Collection available with author. Author is landowner and site is available for fieldwork.

\section{NA202 Stevens Site}

Drainage: Loco (Bailey Creek)

Prior Investigations: Minor excavation and screening by R. L. Turner, Sr. and R. L.

Turner, Jr. in late 1930s. Recorded by Jim Corbin, 11/27/96.

Ceramics: sherds (per Robert L. Turner, Jr.)

Lithics: Uncertain

Historic Artifacts: glass beads

Conclusion: Historic Caddo site.

Research Potential: Unknown

\section{Lanana Sites}

\section{NA113}

Drainage: Lanana

Prior Investigations: Recorded by Jim Corbin, 7/18/77.

Ceramics: "mainly sandy paste, punctated and brushed". TOTAL $=22$. "Burial containing two small ceramic vessels, glass trade beads and shell beads. One vessel is Patton Engraved."

Lithics: no arrow points.

Historic Artifacts: glass beads.

Conclusion: Historic Caddo site.

Research Potential: Collection at SFASU (Native American Graves Protection and Repatriation considerations; Caddo permission and involvement required.) Site may belong to a Mr. Drewry.

\section{NA206 Steve Spradley Site}

Drainage: Lanana

Prior Investigations: Recorded by Tom Middlebrook, 3/16/97. East Texas

Archeological Society tested site 10/31/97 with six 1 × 1 m units. SFASU conducted three field schools on the site under direction of Jim Corbin and Victor Galan.

Ceramics: per SFASU

Lithics: per SFASU

Historic Artifacts: per SFASU

Conclusion: Historic Caddo site.

Research Potential: Extensive collection available at SFASU. Landowner has given permission for fieldwork.

41NA223 1804 Guadalupe del Pilar

Drainage: Banita Creek

Prior Investigations: Recorded by Jim Corbin, 4/18/99.

Ceramics: per SFASU

Lithics: per SFASU 
Historic Artifacts: Present, per SFASU.

Conclusion: "proto-historic/historic" Caddo site and/or 1804 mission church

Research Potential: Collection available at SFASU. Site is currently covered in a parking lot.

\section{NA-Unrecorded Site Appleby Bead Site}

Drainage: Lanana

Prior Investigations: Robert L. Turner, Sr. and Robert L. Turner, Jr. excavated and screened for historic glass beads at an unknown site near the headwaters of the Lanana west of Appleby.

Ceramics: per Bob Turner

Lithics: per Bob Turner

Historic Artifacts: glass beads

Conclusion: Historic Caddo site

Research Potential: Location of site is known; but site not visited since 1930s.

\section{NA-Unrecorded Site Nacogdoches East Bead Site}

Drainage: Lanana

Prior Investigations: Robert L. Turner, Sr. and Robert L. Turner, Jr. excavated and screened for historic glass beads at an unknown site east of University Drive.

Ceramics: per Bob Turner

Lithics: per Bob Turner

Historic Artifacts: glass beads

Conclusion: Historic Caddo site

Research Potential: Location of site currently unknown. Potential may be high if the location of the site can be determined.

\section{Attoyac Sites}

\section{NA67 Sam Rayburn \#101}

Drainage: Attoyac

Prior Investigations: Recorded by Mayhew, 9/22/73.

Ceramics: Caddo only: Plain $=275$, Brushed $=33$, Incised $=72$, Punctated $/$ Incised $=27$, Brushed $/$ Punctated $=1$, Neck banded=1, Engraved $=6$, Punctated $=37$, Other $=6$. Two illustrated sherds may be Patton. TOTAL $=458$.

Brushed $\%=7.2 \%$

Lithics: Perdiz=7, Friley=2, Maud(?)=1, Bassett=1.

Historic Artifacts: Brass tinkler=1, Glass bead (blue)=1, Historic Sherd (blue floral hand painted) $=1$.

Conclusion: This is a multi-component site with Paleoindian, Archaic, Woodland (Mossy Grove), and Early/Middle/Late/Historic Caddo all possibly being present. Research Potential: Mayhew collection available at TARL. Site highly disturbed by reservoir and 40 years of looting.

\section{NA-Unrecorded Site Joe Little Site}


Prior Investigations: Surface collection and minimal excavation by J. H. Burr, 1960. Collection of 13 vessels procured by Gene Haley (now deceased). Site completely destroyed by obtaining fill for road construction of nearby FM138.

Ceramics: Sherds not yet inventoried. Vessels: bottles $=6$, bowls $=3$, jar $=3$

Lithics: Not yet inventoried.

Historic Artifacts: One earthenware vessel in European pitcher form.

Conclusion: Multi-component site with protohistoric and Historic Caddo artifacts.

Research Potential: Availability of Haley material for study is unknown. Burr artifacts available with the author.

\section{Note Concerning San Augustine County Attoyac Bayou Sites}

There are a number of sites on the eastern side of the Attoyac Bayou (and just outside Nacogdoches County) that may have Historic Caddo components. The Jack Walton site (4ISA 135) which the author excavated in the 1980s, had a few Patton Engraved sherds. The McElroy site (41SA I16) is known for burials with glass trade beads; Ed Jelks conducted limited excavations there in the early 1960s as part of the McGee Bend Reservoir project. The nearby Luther Howell site, just to the northeast of McElroy, had at least one Natchitoches Engraved bowl. These and other nearby sites need further investigation.

\section{Comments}

The overall number of Historic Caddo sites known in Nacogdoches County is relatively small. Sites generally are clustered in the western portions of the county, especially along Bayou Loco and Legg Creek. Future analysis of sites along individual streams and comparison to other cluster of sites may begin to help us understand the archaeological signature of individual constituent groups. Aggressive site-seeking surveys of the eastern one-half of the county (and the Moral and Alazan basins) are needed.

Historic Caddo sites cannot simply be defined by the presence of European trade materials; only one historic artifact was recovered in 22 cubic meters of deposit at the Henry M site while only four beads were recovered at Deshazo in 163 cubic meters of excavated archaeological deposits. Understanding the Caddo ceramics of Historic native sites will be essential for workers in this area. 


\section{References Cited}

Berlandier, J. L.

1969 The Indians of Texas in 1830. Edited by J. C. Ewers. Smithsonian Institution Press, Washington, D.C.

Bolton, H. E.

1915 Texas in the Middle Eighteenth Century: Studies in Spanish Colonial History and Administration. University of California Press, Berkeley.

Kenmotsu, N. A.

1992 The Mayhew Site: A Possibile Hasinai Farmstead, Nacogdoches County, Texas. Bulletin of the Texas Archeological Society 63:135-174.

Kenmotsu, N. A. and T. K. Perttula (editors)

1993 Archeology in the Eastern Planning Region, Texas: A Planning Document. Cultural Resource Management Report 3. Department of Antiquities Protection, Texas Historical Commission, Austin.

Marceaux, $\mathrm{S}$.

2006 A Caddo 'Confederacy': Archaeological and Historical Evidence of the Hasinai. Dissertation Prospectus. The University of Texas at Austin. November 14, 2006.

Prewitt, E. R.

1975 Bayou Loco: Investigations and Speculation. Paper presented at the 1975 Caddo Conference, Texas A\&M University, College Station.

Story, D. A., J. A. Guy, B. A. Burnett, M. D. Freeman, J. C. Rose, D. G. Steele, B. W. Olive, and K. J. Reinhard

1900 The Archeology and Bioarcheology of the Gulf Coastal Plain. Research Series 38. 2 Vols. Arkansas Archeological Survey, Fayetteville. 